Журнал«Герспективитаінноваціїнауки»

(Серія«Гедагогіка», Серія«Гцихологія», Серія«Медицинв»

№2(7) 2022

УДК: $378.013+153.8+370.154$

https://doi.org/10.52058/2786-4952-2022-2(7)-822-831

Водолазська Ольга Олегівна кандидат психологічних наук, доцент кафедри загальної та диференціальної психології, Державний заклад «Південноукраїнський національний педагогічний університет імені К.Д.Ушинського», вул. Старопортофранківська, 26, Одеса, 65020; тел.: (067) 781-65-87, https://orcid.org/0000-0003-1769-0258

\title{
ПРЕДИКТОРИ ПРОФЕСІЙНОГО СТАНОВЛЕННЯ МАЙБУТНІХ ПСИХОЛОГІВ
}

Анотація. У статті подано результати емпіричного дослідження мотивації досягнень та мотивації уникнення невдач як предикторів професійного становлення особистості майбутніх психологів. Специфіка суспільно-економічного розвитку сучасного суспільства вимагає від особистості пошуку найбільш оптимальних шляхів професійного становлення. Усвідомлення майбутніми психологами труднощів оволодіння професійними навичками спонукає людину до пошуку альтернативних можливостей реалізації особистісного потенціалу. Уміння оцінювати себе і свої дії у виконуваній професії, ставитися до себе певним чином надає можливості людині, яка отримує професію психолога, формувати себе як професіонала, співвідносити шляхи вирішення професійних завдань 3 сукупністю притаманних особистості мотивів, спрямовуючи їх на реалізацію поставленої мети. Емпіричне дослідження було проведено за допомогою наступного методичного інструментарію: «Опитувальник самоставлення» В.В.Століна та С.Р.Пантилеєва; «Методика діагностики особистості на мотивацію до успіху та мотивацію уникнення невдач» Т.Елерса; «Фрайбурзький особистісний опитувальник (FPI)», модифікована форма В (Й.Фаренберг, Х.Зарга). Аналіз отриманих даних емпіричного дослідження дозволив визначити психологічні особливості самоставлення та прояву властивостей особистості у представників вибірки майбутніх психологів з високим рівнем мотивації досягнення успіху та високим рівнем уникнення невдач. За результатами якісного аналізу вивчено та охарактеризовано психологічні портрети осіб з різним рівнем мотивації досягнення успіху та мотивації уникнення невдач. Перспективи дослідження передбачають вивчення індивідуально - типологічних особливостей як предикторів професійного становлення майбутніх психологів.

Ключові слова: професійне становлення, самоставлення, мотивація досягнення успіху, мотивація уникнення невдач, властивості особистості.

Vodolazska Olga Olehivna Candidate of Psichological Sciences, Associate Professor, Associate Professor of the Department of General and Differential Psychology, State Institution "South ukrainian National Pedagogical University named after K.D. Ushinsky", Staroportofrankivska St., 26, Odessa, 65020, tel.: (067)781-65-87, https://orcid.org/0000-0003-1769-0258 


\section{PREDICTORS OF PROFESSIONAL FORMATION FUTURE PSYCHOLOGISTS}

Abstract. The article presents the results of an empirical study of achievement motivation and motivation to avoid failure as predictors of professional development of future psychologists. The specifics of socio-economic development of modern society requires the individual to find the most optimal ways of professional development. Awareness of future psychologists of the difficulties of mastering professional skills encourages a person to seek alternative opportunities to realize personal potential. In Artikle presents the of results of theoretical and empiricalresearch of self-esteem and motivation of achievements as predictors of professional development of the personality of future psychologists. It is the ability to evaluate themselves and their actions in the profession, to treat themselves in a certain way gives opportunities to a person who receives the profession of a psychologist, to form himself as a professional, to correlate the ways of decision of professional tasks with totality of inh erent to personality reasons, sending them to realization of the put aim. The empirical study was conducted using the following methodological tools: «SelfAssessment Questionnaire» by V.Stolin and S. Pantileev; «Methods of diagnosing personality vor motivation to succeed and motivation to avoid failure» T.Ehlers; «Freiburg Personal Questionnaire (FPI)», modified form B (J.Fahrenberg, H.Zarga). According to the results of qualitative analysis, psychological portraits of people with different levels of motivation to succeed and motivation to avoid failure were studied and characterized. Prospects for the study include the study of individual-typological features as predictors of professional development of future psychologists.

Keywords: professional development, self-attitude, motivation to succeed, motivation to avoid failures, personality traits.

Постановка проблеми. Проблема професійного становлення майбутнього фахівця безпосередньо пов'язана 3 питаннями засвоєння професійних знань та умінь, розвитку і реалізації свого особистісного та професійного потенціалу. Сучасні умови соціально-економічного розвитку суспільства спонукають особистість до ефективності реалізації себе у професії, як однієї з важливих проблем людського існування. Важливі вимоги висуваються до психологів, як представників суб'єкт-суб'єктних спеціальностей , яким властиве не лише змістовне оволодіння професією, а й можливо, у більшій мірі, уміння, пов'язані 3 реалізацією людського потенціалу. Належність сформованої професійної свідомості надає можливість вибрати альтернативні сценарії подальшого професійного становлення, і не обов'язково в межах отриманих знань [4]. У людини, яка опановує професію психолога, як другу, виникає потреба в подальшому розвитку самосвідомості та самоорганізації, що детермінується сукупністю внутрішніх спонукань.

Аналіз останніх досліджень і публікацій. У вітчизняній психологічній науці за останні роки з'явилась достатня кількість робіт, присвячених питанням 
професійного становлення особистості. Даний феномен можна визначити , 3 одного боку, як процес формування ставлення до професії, рівень емоційноособистісного залучення до неї, з другого - накопичення досвіду практичної діяльності, професійне вдосконалення та отримання професійної майстерності. Питання професійного становлення особистості висвітлюють у своїх дослідженнях Т.В.Алексеєва, М.Й.Боришевський, Л.Ф.Бурлачук, Ю.М.Забродін, Є.Ф.Зеєр, О.В.Карпов, Є.О.Клімов, С.Д.Максименко, В.Ф.Моргун, В.Г.Панок, Ю.П.Поваренков, В.А.Татенко, Т.М.Тітаренко, О.П.Саннікова, М.В.Савчин, Н.В.Чепелєва, Т.С.Яценко, В.Д.Шадріков та ін. У відповідності $з$ метою дослідження ми дотримуємось напрямку досліджень Є.Ф.Зеєра, де професійне становлення особистості розглядається як процес прогресивної зміни особистості під впливом соціальних дій професійного становлення і особистісної активності, спрямованої на розвиток самоставлення та самоздійснення.

Здатність особистості до самоставлення - виняткове надбання людини, яка має можливість пізнавати та усвідомлювати себе як суб'єкта дій, стаючи об’єктом безпосереднього ставлення до самої себе. Підсумковим продуктом процесу самопізнання є, по-перше, динамічна система уявлень людини про себе, свої можливості, якості і місце серед інших людей (І.С.Кон, Г.В.Лозова, O.O.Реан, I.I. Чеснокова та ін.). По-друге, те, чого досягає в своєму житті людина, у вирішальній мірі залежить від розвитку мотивації досягнення, що виявляється в сукупності спонукань, які викликають активність особистості та визначають iï спрямованість [6]. Феномен професійного самоставлення особистості вивчається протягом багатьох років, але в дослідженнях як вітчизняних, так i зарубіжних вчених недостатня увага приділяється взаємозв'язку зазначеного феномену з мотивацією особистості. На наш погляд, такий взаємозв'язок є запорукою прояву активності особистості для досягнення успіхів у професійній діяльності.

У вітчизняній психології фундаментальні дослідження феномену ставлення до себе викладені в роботах М.І.Лісіної, Д.В.Ольшанського, О.Г.Спіркіна, В.В.Століна, С.Р.Пантилеєва, С.Л.Рубінштейна, І.І.Чеснокової, К.В.Шорохової та багатьох інших учених. В зарубіжній психології даний феномен розглядався в працях А.Адлера, А.Бандури, Р.Бернса, І.Брандена, У.Джемса, Ф.Зімбардо, К.Левіна та ін. Більшість авторів вважають, що самосвідомість опирається на два основних компоненти: когнітивний і емоційний. Однією 3 складових когнітивного компоненту $є$ знання особистості про себе, а емоційного самоставлення [1]. Незважаючи на істотні розбіжності учених в розумінні феномену самоставлення, він відображає такий бік ставлення людини до себе, як іiі почуття "за" або "проти" себе. Ці почуття характеризуються відносною стійкістю, амодальністю, недиференційованістю й мало залежать від актуального самосприйняття. При цьому почуття "за" або "проти" себе традиційно розглядаються як стійка риса особистості, що складається поступово й здобуває характер усталеності [8]. 
3 точки зору I.І.Чеснокової, самоставлення $є$ афективним утворенням особистості, результатом інтеграції самопізнання й емоційно-ціннісного ставлення до себе [9] або загальним почуттям "за" або "проти" себе, що виражає сукупність позитивних і негативних моментів [8].

Безпосередньо для нашого дослідження $\epsilon$ значущою обставина, яка визначає факт взаємозалежності самоставлення у період професійного становлення від мотивації. Пояснюється це наступним. Будь-яка людина, «входить» до професії уже сформованою особистістю і визначає ставлення до себе особливими професійними умовами. Разом з тим, у процесі професійного становлення майбутнього психолога перед кожним суб'єктом постає завдання значного посилення особистісного потенціалу зі специфічними для нього мотивами. Саме сукупність мотивів, як складових елементів психіки людини, розкриває як усталені психологічні утворення особистості, так і спонукає до розвитку нових, що $є$ визначенням породження активності суб'єкта під час освоєння фахових знань і умінь.

Мотивація - структурне утворення, елементами якого $є$ досягнення успіху й уникнення невдач [6]. У свою чергу, ці елементи складаються з наступних компонентів: потреба досягнення мети і іiі антиципація, інструментальна активність, афективний стан, результат діяльності і ставлення до цього оточуючих. Найбільшу значущість i інтерес для науковців представляють форми мотивації, які виявляються в різних формах діяльності: професійній, науковій, навчальній. Саме вони визначають творче, ініціативне ставлення до мети, впливають на характер і якість виконання праці. Одним із основних видів мотивації є мотивація досягнення, яка характеризує внутрішнє, відносно стійке прагнення до успіхів в різних видах діяльності. Першим, хто виокремив подібний вид мотивації, був Г.А.Мюррей. Саме він включив мотивацію досягнення у список потреб як «потребу досягнення». Згідно 3 теорією Дж. Аткінсона, всі люди володіють одночасно і мотивом досягнення, і мотивом уникнення невдач. I в ситуації вибору у людини виникає конфлікт між тенденцією прагнути до успіху, яка викликає дії, що ведуть до успіху, і тенденцією уникнути невдачі, яка пригнічує дії, що ведуть до невдачі. Вдосконалення моделі Дж.Аткінсона було здійснено Н.Фізером, який ввів поняття зовнішньої мотивації. Він вважав, що загальна тенденція виконати завдання $є$ сумою результуючої тенденції прагнення до успіху й уникнення невдачі і зовнішньої мотивації виконання завдань [4].

Отже, аналіз наукових досліджень спонукав нас до припущення, що бажання засвоєння нових професійних знань залежить від усвідомлення рівня складності фахових завдань під час професійного становлення та збереження особистістю на належному рівні ставлення до себе як майбутнього професіонала. Зазначене дозволило нам висловити припущення про взаємозв'язок самоставлення особистості з мотивацією на шляху професійного становлення. 
Журнал«Герспективитаінновації наукиљ

(Серія«Гедагогіка», Серія«Гцихологія», Серія«Медицинв»

№2(7) 2022

Мета статті - викладення результатів дослідження взаємозв'язку показників самоставлення, мотивації досягнення та властивостей особистості, що у своєму поєднанні стають предикторами професійного становлення особистості майбутнього психолога.

Виклад основного матеріалу дослідження. Емпіричне дослідження було організоване 3 метою пошуку взаємозв'язку показників самоставлення осіб 3 високим рівнем мотивації досягнень та осіб 3 високим рівнем мотивації уникнення невдач.

3 огляду на мету дослідження була підібрана вибірка, яку склали здобувачі відділення перепідготовки фахівців за магістерською програмою із психології Державного закладу «Південноукраїнський національний педагогічний університет імені К. Д. Ушинського». Комплексним дослідженням було охоплено 56 осіб, із них - 49 жінок та 7 чоловіків, віком 22-59 років. Для проведення емпіричного дослідження ми використали наступний методичний інструментарій: «Опитувальник самоставлення» В.В.Століна та С.Р.Пантилеєва; «Методика діагностики особистості на мотивацію до успіху та мотивацію уникнення невдач» Т.Елерса; «Фрайбурзький особистісний опитувальник (FPI)», модифікована форма В (Й.Фаренберг, Х.Зарга). Математико-статистична обробка отриманих даних здійснювалася методами кількісного (рангова кореляція за Спірменом в програмі SPSS, версія 13.0) та якісного аналізу.

Результати та їх обговорення. Загалом, результати кореляційного аналізу підтвердили можливість зіставляти психологічні характеристики психологічних явищ, які вивчаються, та дозволили здійснити якісний аналіз отриманих даних. 3 цією метою були проаналізовані профілі самоставлення (рисунок 1) та профілі властивостей особистості (рисунок 2) двох груп досліджуваних - 3 високим рівнем мотивації досягнення успіху (19 осіб) та з високим рівнем мотивації уникнення невдач (18 осіб), які були попередньо обрані за допомогою методу «асів».

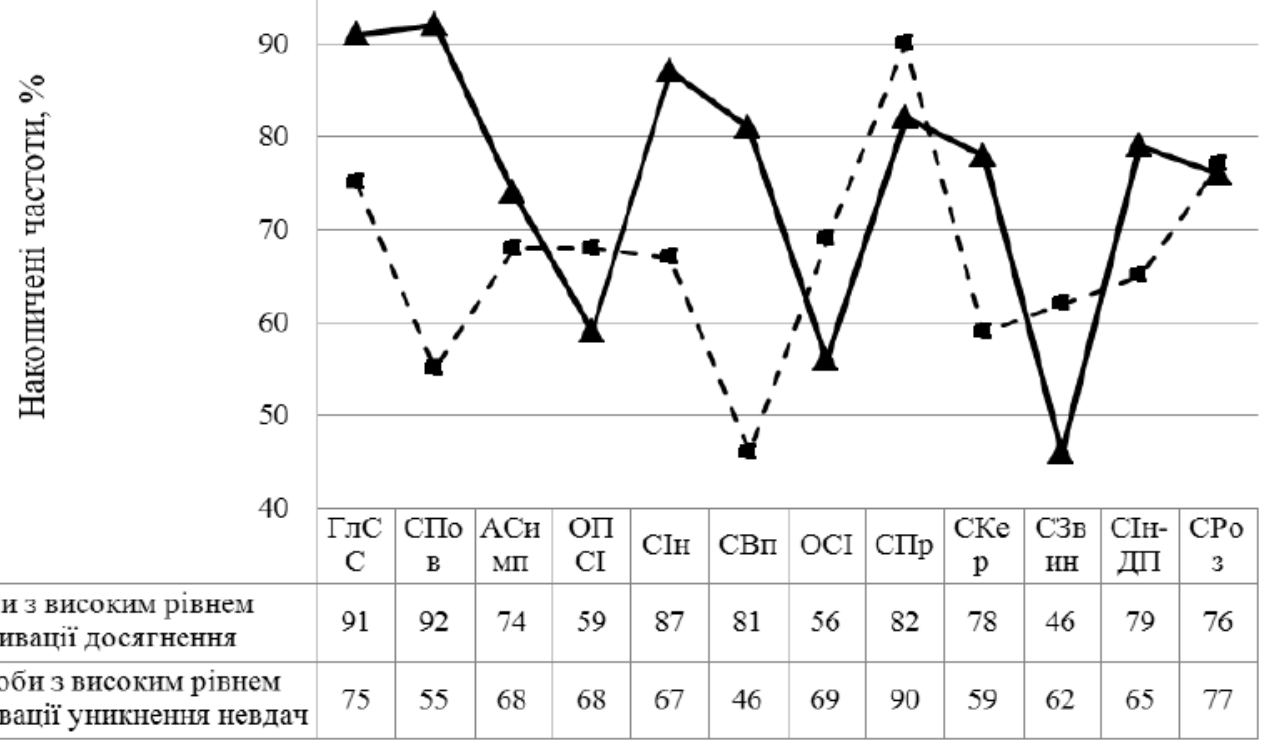

Рис.1. Профілі самоставлення осіб з високим рівнем мотивації досягнення успіху та осіб з високим рівнем мотивації уникнення невдач. 
Примітка. Показники самоставлення: ГлСС - глобальне самоставлення, СПов - самоповага, АСимп - аутосимпатія, ОПСІ - очікування позитивного ставлення від інших, СІн - самоінтерес, СВП - самовпевненість, ОСІ очікування ставлення інших, СПр - самоприйняття, СКер - самокерівництво, СЗвин - самозвинувачення, СІн-ДП - самоінтерес (диференціальний показник), СРоз - саморозуміння.

Отже, профілі самоставлення означених груп досліджуваних подано на рис.1. На осі абсцис розташовані показники самоставлення, на осі ординат - їх значення, що надані у процентилях. Через точку 50 процентилів проходить середня лінія ряду (максимальна кількість процентилів дорівнює 100). Значення кожного показника у профілях $\epsilon$ середнім арифметичним значенням даного показника у представників кожної групи. Враховуючи те, що показники самоставлення є біполярними, ступінь вираженості того чи іншого показника визначається за його відхиленням від середньої лінії ряду. Спочатку розглянемо кожний профіль окремо, а потім здійснимо порівняльний аналіз між зазначеними профілями.

В цілому можна відмітити, що хоча значення показників самоставлення представників обох груп знаходяться в діапазоні 46-92\%, профілі не можна назвати однорідними. В групі з високим рівнем мотивації досягнення успіху пікових значень набувають показники глобального самоставлення (ГлСС) та самоповаги (Спов). Найнижчого значення в даній групі набуває показник Сзвин (самозвинувачення). Профіль самоставлення групи з високим рівнем мотивації уникнення невдач $є$ більш однорідним. Пікові значення співвідносяться 3 показником СПр (самоприйняття), a найнижчі значення відповідають показнику самовпевненості (СВп). Візуальне порівняння профілів осіб 3 високим рівнем мотивації досягнення успіху та високим рівнем мотивації уникнення невдач показує найбільші розбіжності в таких показниках, як:Спов (самоповага), СВп (самовпевненість). Візуально відмічаються дуже близькі значення двох груп за такими показниками самоставлення:СРоз (саморозуміння), СПр (самоприйняття), АСимп (аутосимпатія).

На рисунку 2 представлено профілі властивостей осіб з високим рівнем мотивації досягнення успіху та осіб з високим рівнем мотивації уникнення невдач. Вісь абсцис має розташування показників властивостей особистості, а на осі ординат надано їх значення, що представлені в «сирих» балах. Середня лінія ряду проходить через точку 5,5 балів. За даними, які висвітлюють профілі властивостей особистості, отримані значення профілів обох груп знаходяться в діапазоні 3-8 стандартних балів. Привертає увагу шкала відвертості, значення якої знаходяться в межах 7-8 стандартних балів. Цей факт свідчить, що респонденти обох груп були досить відверті у дослідженні, довіряли досліднику. 


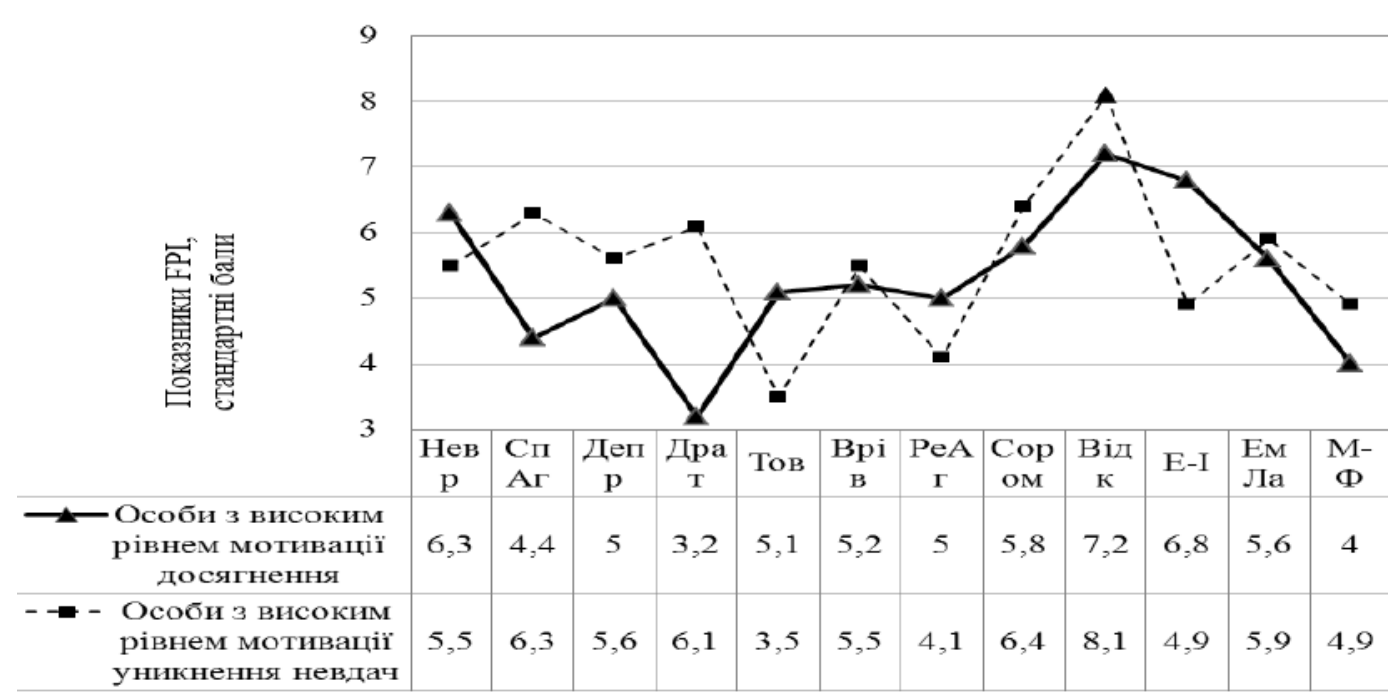

Pис. 2. Профілі властивостей особистості за методикою FPI осіб з високим рівнем мотивації досягнення успіху та осіб з високим рівнем мотивації уникнення невдачі.

Примітка. Показники властивостей особистості: Невр - невротичність, СпАг - спонтанна агресивність, Депр - депрессивність, Драт - дратівливість, Тов - товариськість, Врів - врівноваженість, РеАг - реактивна агресивність, Сором - сором'язливість, Відк - відкритість, Е-I - екстраверсія-інтроверсія, ЕмЛа - емоційна лабільність, М-Ф - маскулінність-фемінність.

Проаналізуємо кожний профіль окремо в порядку зниження значень показників.

Візуальний аналіз профілів показує, що особи з високим рівнем мотивації досягнення успіху характеризуються високим рівнем значень показників відкритості (Відк) та екстраверсії (Е-I), середнім рівнем невротичності (Невр), сором'язливості (Сором), емоційної лабільності (ЕмЛа), товариськості (Тов), депресивності (Депр), врівноваженості(Врів) та реактивної агресивності (РеАг). Привертають увагу відносно мінімальні значення таких показників, як дратівливість (Драт) та маскулінність (М-Ф). Значення останнього є доволі закономірним для обох груп, оскільки за статевим складом вони є повністю жіночими. Аналіз профілю групи осіб з високим рівнем мотивації уникнення невдач показує, що цим людям притаманна виражена відкритість (Відк), середньо виражені сором'язливість (Сором), дратівливість (Драт), спонтанна агресивність (СпАг), емоційна лабільність (ЕмЛа), врівноваженість (Врів). В меншій мірі у представників даної групи виражені такі властивості, як реактивна агресивність (РеАг) та товариськість (Тов).

В цілому, за візуальним порівнянням, профілі є подібними між собою, проте ми можемо констатувати деякі відмінності за значеннями певних показників. Значення такої властивості, як дратівливість (Драт), у осіб 3 високим рівнем мотивації уникнення невдач виражена доволі високо, тоді як у профілі осіб з високим рівнем мотивації досягнення успіху іiі значення 
найнижчі; значення показника товариськості (Тов) знаходиться на середньому рівні у осіб з високим рівнем мотивації досягнення успіху, а у осіб з високим рівнем мотивації уникнення невдачі наближується до нижньої межі середніх значень; показник спонтанної агресивності (СпФг) має тенденцію до підвищення у осіб групи 3 високим рівнем мотивації уникнення невдачі; показник екстраверсіі-інтроверсії (E-I ) виявив наступні значення: у осіб 3 високим рівнем мотивації досягнення успіху екстраверсія виражена яскравіше, ніж у осіб з високим рівнем мотивації уникнення невдачі. Також слід відмітити показники, які набувають близьких значень в обох групах: врівноваженість (Врів), сором’язливість (Сором), відвертість (Відк) та емоційна лабільність (ЕмЛа).

Аналіз графіків дозволяє скласти психологічні характеристики представників кожної з груп, які різняться рівнем мотивації досягнення.

Особи 3 високим рівнем мотивації досягнення успіху характеризуються досить високим рівнем самокритичності, прагненням до довірливих відносин 3 соціальним оточенням. Можна сказати, що ці люди орієнтовані на події зовнішнього світу, соціальне оточення, де їхня поведінка $є$ досить гнучкою. Вони мають високий рівень соціальної активності, виражену потребу в спілкуванні, в постійній динаміці професійних якостей. Зазначимо високий рівень адаптованості в соціумі, життєрадісності, впевненості в собі та емоційної стійкості, притаманний людям з високим рівнем мотивації досягнення успіху. Для осіб даної групи важлива зовнішня стимуляція, їм притаманне інтенсивне залучення до різних форм професійної активності.

Особам з високим рівнем мотивації уникнення невдач також притаманний високий рівень самокритичності та відвертості. Проте, вони можуть реагувати на звичайні ситуації, які виникають у професійній діяльності, як на стресові. Особам 3 високим рівнем мотивації уникнення невдач також властиві імпульсивність поведінки, нестійкі емоційні стани зі схильністю до афективного реагування. Цим людям притаманна знижена потреба в професійному розвитку та знижена професійна активність. Можна сказати, що в даній групі переважає інтровертованість.

Висновки. 1. Встановлено наявність значущих додатніх зв'язків між показниками самоставлення i мотивації досягнення успіху, а саме: самовпевненістю, самоповагою, самоінтересом, самокерівництвом.

2. Визначено, що особи, які мають досить високу самооцінку, характеризуються стійкою вірою в свої сили, високим ставленням до своїх професійних можливостей, високим рівнем розуміння себе та свого місця в професії. Цим людям притаманний інтерес до власних почуттів та думок, впевненість, що вони можуть подолати ті труднощі, з якими зустрічаються на етапі професійного становлення. Представники вибірки, які за результатами діагностики отримали рівень самооцінки нижче середнього, характеризуються помірним рівнем готовності до самозвинувачення, зниженням віри у свої сили, здібності та можливості. 
3. Виявлено значущі зв'язки показника мотивації досягнення 3 показниками товариськості та екстраверсії, від'ємні зв'язки 3 показниками спонтанної агресивності, особистісної тривожності, дратівливості та сором'язливості.

4. Аналіз відмінностей у психологічних характеристиках осіб з високим рівнем мотивації досягнення та високим рівнем мотивації уникнення невдач дозволяє визначити загальні тенденції. Особи 3 високим рівнем мотивації досягнення успіху характеризуються соціальною активністю, високим рівнем самокритичності, постійною позитивною динамікою професійних якостей, інтенсивністю у залученні різних форм професійної активності. Особи 3 високим рівнем мотивації уникнення невдач характеризуються помірним рівнем готовності до самозвинувачення, завищеним рівнем тривожності, спрямованої на себе, пасуванням перед труднощами, небажанням їх долати, що призводить до підвищення дратівливості, незадоволеності професією, втрати перспектив професійного зростання, а також до виникнення різного роду професійних деструкцій.

Таким чином, вивчені показники мотивації досягнення у тісному зв'язку 3 показниками самоставлення та властивостей особистості стають визначальними у професійному становленні майбутніх психологів. Зазначені аспекти дослідження не вичерпують багаточисленні питання актуальності професійного зростання осіб, які отримують другу вищу освіту психолога. Подальшого вивчення потребує проблема індивідуально-типологічних особливостей як предикторів професійного становлення особистості майбутніх психологів.

\section{Лimepamypa:}

1. Бабиянц К.А., Коломийченко Е.В. Физическая культура как способ формирования позитивного самоотношения у студентов вуза: учебное пособие, доп. и перераб. / Ростов-наДону; Таганрог: изд-во Южного федерального университета, 2018. 102 с.

2. Гиппенрейтер Ю.Б. Введение в общую психологию: курс лекций. Москва: АСТ: Астрель, 2008. 352c.

3. Зверева Р.Г. Психологические детерминанты развития мотивации достижения успеха у студентов: автореф. дис. ...канд. психол.наук: 19.00.07/ ГОУ ВПО «Пятигорский государственный лингвистический университет». Пятигорск, 2010. 20 с.

4. Зеер Э.Ф. Психология профессий: Учебное пособие для студентов вузов 3-е изд., перераб., доп. Москва: Академический Проспект; Фонд «Мир», 2005. 336с.

5. Зимняя И.А. Педагогическая психология. Москва: Логос, 2004. 384c.

6. Психология. Словарь. / Под ред. А.В.Петровского и М.Г.Ярошевского. Москва: Политиздат, 1990. 494c.

7. Самосознание и защитные механизмы личности. Хрестоматия./ Редактор-составитель Д.Я.Райгородский. Самара: Издат.Дом «БАХРАХ-М», 2000. 656с.

8. Столин В.В. Познание себя и отношение к себе в структуре самосознания личности:Автореф. дисс... д-ра психол. наук: 19.00.01/ Москва,1985.37с.

9. Чеснокова И.И. Проблема самосознания в психологии. Москва: Наука, 1977. 144c.

\section{References:}

1. Babijanc, K.A., Kolomijchenko, E.V. (2018). Fizicheskaja kul'tura kak sposob formirovanija pozitivnogo samootnoshenija u studentov vuza [Physical culture as a way to form a 
positive self-attitude among university students]. Rostov-na-Donu; Taganrog: izd-vo Juzhnogo federal'nogo universiteta [in Russian].

2. Gippenrejter, Ju.B. (2008). Vvedenie v obshhuju psihologiju [Introduction to General Psychology]. Moskva: AST: Astrel' [in Russian].

3. Zvereva, R.G. (2010). Psihologicheskie determinanty razvitija motivacii dostizhenija uspeha $\mathrm{u}$ studentov [Psychological determinants of the development of motivation to achieve success among students]. Extended abstract of candidate's thesis. Pjatigorsk: GOU VPO «Pjatigorskij gosudarstvennyj lingvisticheskij universitet» [in Russian].

4. Zeer, Je.F. (2005). Psihologija professij [Psychology of professions]. (vol. 1-3). Moskva: Akademicheskij Prospekt; Fond «Mir» [in Russian].

5. Zimnjaja, I.A. (2004). Pedagogicheskaja psihologija [Pedagogical psychology]. Moskva: Logos [in Russian].

6. Petrovskiy, A.V. Jaroshevskiy, M.G. (1990). Psihologija [Psychology]. Moskva: Politizdat [in Russian].

7. Rajgorodskij, D.Ja. (2000). Samosoznanie i zashhitnye mehanizmy lichnosti [Self-awareness and protective mechanisms of personality]. Samara: Izdat.Dom «BAHRAH-M» [in Russian].

8. Stolin, V.V. (1985). Poznanie sebja i otnoshenie k sebe v strukture samosoznanija lichnosti [Self-knowledge and attitude towards oneself in the structure of self-consciousness of the individual].Extended abstract of Doctor's thesis. Moskva [in Russian].

9. Chesnokova I.I. (1977). Problema samosoznanija $v$ psihologii [The problem of selfconsciousness in psychology]. Moskva: Nauka [in Russian]. 